\title{
CASE COMMENT: WILLICK v. WILLICK: APPEALS FROM AWARDS UNDER THE ARBITRATION ACT
}

\author{
WILLIAM H. HURLBURT, Q.C.
}

\section{INTRODUCTION}

This note is about the arbitration-law aspects of the recent decision by Justice Deyell in Willick v. Willick, ${ }^{\prime}$ which may be of interest to those who draft arbitration clauses and references to arbitration. The note does not address the substantive family law issues in the case.

\section{SUMMARY}

The issues dealt with by this note are as follows:

1. The judge held that the arbitration agreement, through the words quoted below, provided for appeals from the arbitration award under s. 44(1) of the Arbitration Act. $^{2}$ It is suggested that, though the parties may well have intended to provide for such appeals, it is not at all clear that they did so. The implications of this are that drafters should watch their language so as to make it clear whether a s. 44(1) appeal is or is not wanted by the parties.

2. The judge held that the proper standard of review in an appeal on law under s. 44(1) is the "correctness" or "judicial" standard. This note agrees with this position. The judge indicated that the "correctness" standard is also the proper standard in an appeal on fact under s. 44(1). This note raises doubts about this, but suggests that the "correctness" standard is the proper standard in an appeal on law under s. 44(2), a question that the judgment did not have to deal with.

3. The judge held that, by referring to "spousal support" and "such other issues that arise out of the above," the parties "expressly referred" a question of law to the arbitrator, so that s. 44(3) barred an appeal on law. The note takes issue with this stance on the grounds that a reference to a dispute in general terms is not an express reference to questions of law that arise in the course of the arbitration of the dispute.

4. The judge said that the Court has power to quash an award on the basis of "gross error of law" on the face of the record. This note takes issue with this position as well, on the grounds that the Arbitration Act provides a comprehensive scheme for court intervention in awards and thus displaces any common-law jurisdiction to quash awards.

Director Emeritus, Alberta Law Reform Institute and Counsel, Reynolds Mirth Richards and Farmer.

(2 August 1994), No. $4801-76633$ (Alta. Q.B.) [hereinafter Willick].

S.A. 1991, c. A-43.1. 


\section{FACTS OF THE CASE}

In Willick, the arbitration agreement in question provided that the award shall be "final and binding upon the parties ... subject however to the rights of appeal in s. 44 of the Act." ${ }^{3}$ The provision for submission to arbitration was as follows:

The parties shall submit to arbitration under the terms and conditions hereinafter set out in the following issues:

(a) evaluation of matrimonial property;
(b) division of matrimonial property;
(c) spousal support;
(d) costs;
(e) such other issues that arise out of the above.

The arbitrator awarded Mrs. Willick $\$ 1,000$ per month for twelve months in spousal support. Mrs. Willick appealed the time period.

\section{THE ACT}

Sections 44(1), (2) and (3) of the Arbitration Act are fundamental to the discussion. They are as follows:

44(1) If the arbitration agreement so provides, a party may appeal an award to the court on a question of law, on a question of fact or on a question of mixed law and fact.

(2) If the arbitration agreement does not provide that the parties may appeal an award to the court on a question of law, a party may appeal an award to the court on a question of law with leave, which the court shall only grant if it is satisfied that

(a) the importance to the parties of the matters at stake in the arbitration justifies an appeal, and

(b) determination of the question of law at issue will significantly affect the rights of the parties.

(3) Notwithstanding subsections (1) and (2), a party may not appeal an award to the court on a question of law which the parties expressly referred to the arbitral tribunal for decision.

Essentially, ss. 44(1), (2) and (3) give the parties the following options: 
(1) if they make specific provision for it in the arbitration clause or reference to arbitration, they can have an appeal on law, fact, or mixed law and fact under s. $44(1)$;

(2) if they do not provide for an appeal (or even if they try to exclude the s. 44(2) appeal), they will have an appeal on a question of law, subject to a requirement of leave, and only if the court is satisfied of the things set out in ss. 44(2)(a) and (b); and

(3) if they "expressly refer" a question of law to the arbitral tribunal, they will exclude an appeal on that question.

If a question of law is "expressly referred", s. 44(3) overrides the right to appeal on a question of law under either s. 44(1) or s. 44(2), unless the parties exclude s. 44(3). The interpretation of s. $44(3)$ is discussed later in this note.

\section{WHEN AN AGREEMENT "SO PROVIDES" (s. 44(1))}

An appeal under s. 44(2) is an appeal on law only, and can be brought only with leave if the court is satisfied that the requirements in s. 44(2)(a) and (b) have been met. An appeal under s. 44(1), on the other hand, is of right, and it can include an appeal on law, fact, or mixed law and fact. A party will have a right of appeal under s. 44(1) only "[i]f the agreement so provides."

Justice Deyell dealt with Willick as an appeal under s. 44(1). His reasons for doing so appear to be included in the following passage:

In the case at bar, the Arbitration Agreement entered into by both parties clearly states that the award shall be "final and binding upon the parties ... subject however to the rights of appeal in S.44 of the $A C t$ [emphasis added]. If the statute provides certain rights which the parties expressly take advantage of, effect must be given to the intention of the parties as evidenced in their agreement.'s

These words quoted did not clearly say that s. 44(1) was to apply or that there were to be appeals as of right on law, on fact, and on mixed law and fact. Indeed, it could be argued that the emphasized words incorporate only rights of appeal that s. 44 itself confers, and that s. 44(1) does not confer a right of appeal, but only confirms a right of appeal that the parties confer. On the other hand, s. 44(2) confers only one right of appeal, and a reference to "rights" of appeal may therefore show an intention to incorporate the rights of appeal under s. 44(1).

The judge's interpretation may be correct. The judgment does not suggest that the respondent resisted the appeal on the grounds that no leave had been obtained, and his acquiescence suggests that the parties did intend that there should be a s. 44(1) appeal. However, drafters of arbitration clauses should note that a provision that did not properly address itself to the question of s. 44(1) appeals was construed as "so providing" in order to bring into play s. 44(1). 
Where parties do not want a wide-open right of appeal under s. 44(2), the drafters of their arbitration clause should word the clause carefully so as not to leave room for it to be construed as "so providing" under s. 44(1). Where the parties want a wide-open right of appeal, the drafters should then specifically provide that s. 44(1) applies, or that there is a right of appeal on law, a right of appeal on fact, or a right of appeal on mixed law and fact, depending on what is desired. It is worth the drafters' time to take a moment to consider what range of appeals should be available and to draft the arbitration clause or reference accordingly.

\section{STANDARD OF REVIEW}

\section{A. SECTION 44(1): APPEALS ON LAW}

The Court in Willick stated that there are three possible standards of review of arbitrators' decisions. That is, there are three possible choices of tests that the Court could apply to determine whether an arbitrator's decision is to stand. ${ }^{6}$ These tests, in descending order of stringency, are: (a) the decision will stand only if it is right (the "correctness" standard or the "judicial" standard); (b) the decision will stand unless it is "patently unreasonable" (the "patently unreasonable" standard); or (c) the decision will stand if the tribunal addressed the issue, no matter what the outcome (the "utmost deference" standard). ${ }^{7}$

The Court noted that a "pragmatic or functional approach" is to be taken to determine which standard of review is to apply. This involves consideration of "the wording of the enactment, the purpose of the statute, the reason for the tribunal's existence, the expertise of its members and the nature of the problem." ${ }^{18}$ The existence of a privative clause leads in the direction of a "patently unreasonable" standard, while the existence of a statutory right of appeal leads in the direction of a "correctness" standard, but neither is conclusive.

The Court also noted that even under the previous Arbitration $A c t,{ }^{9}$ where there was no statutory right of appeal (though there was a power to set aside for "misconduct")

Ibid. at 5-6.

There was no suggestion that the "utmost deference" standard should apply, therefore it does not appear again in this discussion.

The principal authorities cited on this point are U.E.S., Local 298 v. Bibeault, [1988] 2 S.C.R. 1048 and Pezim v. British Columbia (Superintendent of Brokers) (23 June 1994) No. 23107, 23113 (S.C.C.).

, R.S.A. 1980 , c. A-43. 
and where there was something that resembled a privative clause, ${ }^{10}$ the Court of Appeal had held that the "correctness" standard applied."

In Willick, therefore, the judge concluded that the "correctness" standard applied to this appeal as well. He noted that there is no privative clause in the Arbitration Act (1991), other than s. 37, "which merely states that an award binds the parties unless set aside or varied under sections 44 or $45 .{ }^{12} \mathrm{He}$ said: "[n]othing in the Arbitration Act (1991) indicates that anything other than the correctness standard ought to apply." ${ }^{\text {"13 }}$

This decision is unexceptionable. Section $44(1)$, where it applies, says simply that "a party may appeal an award to the court on a question of law...." Section 44(5) then gives the court power to confirm, vary, set aside or remit. There is nothing in $\mathrm{s.} 44$ or elsewhere in the Act to suggest that there should be anything but a full right of appeal. $^{14}$

If an arbitration clause or reference were to prescribe a standard of review for s. 44(1) appeals, such as "patent unreasonableness", the courts would probably recognize that standard. Therefore, if drafters would prefer a "patently unreasonable" test, this should be clearly stated within the arbitration clause.

\section{B. SECTION 44(1) APPEALS ON FACT AND MIXED FACT AND LAW}

The appeal in Willick looks like an appeal on law alone. But the judgment goes on to say:

The Schedule to the previous Act included a provision that an award was "final and binding". Under $\mathrm{s} .2$ of the $A c t$, the submission to arbitration was, in the absence of a contrary intention, deemed to include the provisions of the Schedule. A term implied in a submission is not an ordinary privative clause.

" R.O.M. Construction Ltd. v. Electric Power Equipment Ltd., [1981] 4 W.W.R. 97 (Alta. C.A.). See also my casenote in which I argued that it would be patently unreasonable to apply the "patently unreasonable" test to private non-labour arbitrations: W.H. Hurlburt, "Setting Aside Private NonLabour Arbitration Awards for Errors of Law - Some Recent Decisions" (1988) 26 Alta. L. Rev. 345.

$12 \quad$ Willick, supra note 1 at 10.

13 Ibid. The judge said at page 12 that he was bound by R.O.M. Construction Lid. v. Power Equipment Lid., supra note 11. This may only mean that he was bound by it not to be concerned about the anomaly that results from applying a "correctness" standard in the case of consensual arbitration and the more restricted "patently unreasonable" scope of review in the case of nonconsensual arbitration. It does not seem likely that in the interpretation of the Arbitration Act (1991) he was bound by a decision on the very different Arbitration Act of 1970 or 1980, though an application of a fortiori reasoning might make it applicable.

14 Nor is there any such suggestion in the reports leading up to the enactment of the Arbitration Act (1991). The prototype of s. 44(1) first appeared in the draft Uniform Arbitration Act considered by the Uniform Law Conference of Canada at its 1990 meeting, and the commentary does not say anything on the point: Uniform Law Conference of Canada, Proceedings of the Seventy-Second Annual Meeting (Saint John, August 1990) at 111. 
In the alternative, if the question of spousal support duration is a question of fact or mixed law and fact, thereby falling within s. 44(1) of the Arbitration Act (1991), it is necessary to apply the judicial standard and review the Arbitrator's award as it pertains to time-limited spousal support. ${ }^{15}$

That is, in a s. 44(1) appeal on fact, the award can be set aside if the arbitrator got the facts wrong.

I have some doubt about this. It is true that the language of s. 44(1) does not differentiate between appeals on law and appeals on fact: it says that "a party may appeal ... on a question of law, on a question of fact...," suggesting that the same standard of review should apply to appeals on both law and fact. But traditionally, the courts have respected the fact findings of private consensual arbitrators, setting them aside only in extreme cases, for example, if there is no supporting evidence. That is, the courts have recognized that, insofar as the facts are concerned, the parties have chosen their tribunal and a court should not substitute its view of the facts for that of the chosen tribunal. I think that the courts will be reluctant to decide that an arbitrator believed the wrong person or gave the wrong weight to a piece of evidence and that they will develop a formula that does not involve the substitution of the court's view of the facts for the arbitrator's view. That is, they will not apply the "correctness" standard to arbitrators' findings of fact.

The only point for drafters of arbitration clauses and references here is that if they have a preference for one standard of review, they should clearly state this preference within the arbitration clause.

\section{SECTION 44(2): APPEALS ON LAW}

Section $44(1)$ is based on party agreement, whereas s. 44(2) confers an entirely statutory right of appeal. Section 3 of the Act says that the application of s. 44(2) cannot be altered or varied by the parties to an arbitration agreement, so that s. 44(2) applies whether the parties want it or not.

Section 44(2) provides only for an appeal on law and requires leave from the court, on the condition that the court is satisfied that two specified conditions have been met. It is therefore a much more limited right of appeal than the right that the parties may provide for themselves under s. 44(1).

Does the reasoning that says that a "correctness" standard is to be used in deciding appeals on law under s. 44(1) apply to deciding appeals on law under s. 44(2)? The language is the same in both cases: the parties "may appeal an award to the court on a question of law...." Can it mean different things in the two subsections? 
Justice Deyell made one distinction between the two subsections. Report 51 of the Alberta Law Reform Institute, ${ }^{16}$ he noted, proposed to limit court intervention to questions of law alone, and then only if the court was satisfied of the two conditions set out in s. 44(2). But the Legislature "chose to allow parties, that specifically choose to do so, to create what is in effect another tier of litigation by providing for automatic appeals within their arbitration agreements. This is significant to the legislature's intent."17

That is, the legislative history of s. 44 shows a legislative intention to apply the "correctness standard" to s. 44(1). However, that history does not apply to s. 44(2).

Justice Deyell gave another subordinate reason for choosing the "correctness standard". Section 8 in the schedule to the Arbitration Act (1980), he said, was a privative clause making an award final and binding. But s. 37 of the Arbitration Act (1991) makes an award final and binding,

unless set aside or varied under ss. 44 or 45 . This, in my opinion, indicates an intention that the judicial or correctness standard of review is to apply to an appeal pursuant to s.44(1) since the legislature has allowed the parties, if they so provide, to appeal on the grounds set out in $\mathrm{s.} 44(1) .^{18}$

This is equivocal in relation to s. 44(2). On the one hand, the judge referred to the legislature having provided the s. 44(1) appeal, which suggests that there is something special about it. But, on the other hand, both s. 44(1) and s. 44(2) are included in s. 44, implying that $\mathrm{s} .37$ treats both subsections the same.

Although s. 44(2) does not say in so many words what the standard of review is, the question was certainly present in the minds of the drafters of ALRI Report $51 .^{19}$ The ALRI formed the view that, while the arbitrating public might want to get rid of the trappings of litigation, it most commonly wanted its rights to be determined according to law, not according to arbitrators' whims. Taking this into account, the ALRI's draft Act included s. 44(2), which, subject to addition of a leave requirement, was adopted by the Uniform Arbitration Act and subsequently by the 1991 Arbitration Act. The ALRI's thinking was that, this being an appeal on law, the court should have power to allow the appeal if the arbitrator got the law wrong. That is, the standard of review on appeal should be the "correctness" standard. The following passage appears in Report 51 at page 62: "If an award is wrong in law, a party should be able to appeal against

Institute of Law Research and Reform, Proposals for a New Arbitration Act (Report No. 51) (Edmonton: October 1988). What became s. 44(1) was added in the Uniform Law Conference of Canada proceedings that resulted in the Uniform Arbitration Act (supra note 14). The Arbitration Act (1991) was based directly on the Uniform Arbitration Act and indirectly on the Alberta Law Reform Institute's [hereinafter ALRI] proposals, so that both the ALRI report and the Uniform Law Conference proceedings can be looked at to help to determine what deficiencies the Arbitration Act was directed towards.

17 Willick, supra note 1 at 11 . The legislature actually based the 1991 Act directly on the Uniform Arbitration Act. The prototype of s. 44(1) was in the Uniform Arbitration Act.

19 See for example Hurlbur, supra note 11. 
it to the Court of Queen's Bench..." (subject to satisfying the two conditions). That is a "correctness" standard.

In my submission, the reasoning that applies the "correctness" standard to appeals on law under s. 44(1) applies equally and with the same force to appeals on law under s. 44(2).

\section{SECTION 44(3): QUESTIONS OF LAW "EXPRESSLY REFERRED"}

\section{A. THE JUDGMENT}

The submission quoted in "Facts of the Case" above refers a number of issues to arbitration. One is "spousal support". Another is "such other issues that arise out of the above."

The Court in Willick stated that "the question of spousal support, including duration, is a question of law," and declined to accept the argument that "the general issue of spousal support was referred to the Arbitrator but not the specific issue of duration."20 The Court gave two reasons for rejecting that argument:

First, the question of spousal support was expressly referred to the arbitrator and the question of duration, in my view, forms part and parcel of determining the support order....

Second, ... clause 2(e) of the Arbitration Agreement would be rendered meaningless if "spousal support" in clause 2(c) was to be interpreted as meaning quantum alone....Consequently, I find "spousal support" on its own or read in conjunction with clause 2(e) expressly referred the question of quantum and duration to the Arbitrator for consideration...Accordingly I find that the parties, by virtue of $s$. 44(3), cannot appeal the Arbitrator's award with reference to duration. ${ }^{21}$

The Court referred to the judgment of Justice Prowse in Pachanga Energy Inc. v. Mobil Investments Canada Inc. ${ }^{22}$ In that case, the question for the arbitrator was "[i]n what amount, if any, is Pachanga entitled to compensation in respect to the conveyance by Mobil of its interest in the Matziwan Gas Plant and Gathering System?" ${ }^{23}$ This was a s. 44(2) application for leave, which Justice Prowse first disposed of by saying that the questions raised were mixed fact and law so that there was no appeal under $s$. 44(2). He then went on:

Alternatively, I find that if $I$ am in error in the finding that the issue raised involved fact and law but is a question of law, then I am of the opinion it is that specific question of law which the parties

$20 \quad$ Willick, supra note 1 at 13.

$21 \quad$ Ibid. at 14.

22 (1993), 8 Alta. L.R. (3d) 284 (Q.B.) [hereinafter Pachanga]. Pachanga was upheld on appeal, but the Court of Appeal expressly refrained from dealing with the s. 44(3) issue. 
expressly referred for the determination by the Arbitrator and s. 44(3) bars an appeal from his award. ${ }^{24}$

Essentially, both Willick and Pachanga appear to be saying that the submission of an issue to arbitration "expressly refers" the questions of law that are bound up in the issue, and that consequently there can be no appeal on those questions under s. 44(1) or s. 44(2). I will now suggest that this is not the correct interpretation of s. 44(3).

\section{B. INTENTION OF SECTION 44(3): THE ARBITRATION ACT CONTEXT}

Section 44(3) resulted from a recommendation made to the government in the last discussions that led up to the enactment of the 1991 Act. There is nothing in any document to which reference may be made to show what the intention of the subsection was. As a result, we are left to look at the subsection and its context to determine what it means.

To start with, the context of s. 44(3) includes s. 44(1) and s. 44(2), which state that a party may appeal on a question of law; the difference being that $s$. 44(1) must be activated by the parties, while s. 44(2) requires leave. Subject to the fulfillment of these requirements, the parties are entitle to appeal on law.

However, s. 44(3) then says that there is no appeal on a question of law "which the parties expressly referred to the arbitral tribunal for decision." Section 44(3) makes an exception to both s. 44(1) and s. 44(2) and expressly overrides them.

An arbitration clause or an agreement for the arbitration of an existing dispute refers a dispute to arbitration. It "expressly refers" that dispute. If s. 44(3) is interpreted to mean that expressly referring a dispute to arbitration "expressly refers" all questions of law that have to be decided in order to arbitrate that dispute, there is no office left for the appeal-on-law provisions of ss. 44(1) and (2). It is, in my submission, unlikely that the Legislature intended to confer rights of appeal under ss. 44(1) and (2) and then take them away under s. 44(3). It is necessary to look further to see how extensive an exception s. 44(3) was intended to make to ss. 44(1) and (2).

As noted above, the s. 44(3) exception is "a question of law which the parties expressly referred to the arbitral tribunal for decision." This, in my submission, means that there must be an identifiable question of law which is "expressly referred" to the arbitrator. This may be contrasted with "any question of law that arises during the arbitration," which, under s. 17(2), can be determined by the arbitral tribunal.

If the parties have asked the arbitrator to answer a specific question, they have given at least a surface indication that they want the arbitrator, and not the courts, to answer the question. It therefore makes sense to say that there is no appeal from the arbitrator's answer to a question they have specifically asked. Section $44(3)$ is not outside the 
parties' control: if they want to appeal from the answer to a specifically referred question they can exclude s. $44(3){ }^{25}$

\section{INTENTION OF SECTION 44(3): THE PREVIOUS LAW CONTEXT}

The interpretation that s. 44(3) is intended to cover only the express reference of a specific question of law is supported by the law in existence when the 1991 Act was enacted.

Under the previous $A c t$, and indeed under all the Arbitration Acts that copied the 1889 U.K. Act, ${ }^{26}$ there was no appeal from an award, but a court could quash an award "if the arbitrator has misconducted himself...." "Misconduct" included making an error of law that appeared on the face of the record. The courts had made an exception to this: if a question of law was "the very thing" referred to the arbitrator, the courts would not set the award aside merely because the arbitrator answered it wrongly.

For the purposes of this note it is sufficient to refer to one decision of the Supreme Court of Canada which in turn referred to two decisions of the House of Lords. The Supreme Court of Canada decision is Metropolitan Toronto Police Association v. Metropolitan Toronto Board of Commissioners of Police. ${ }^{27}$ At 653, Justice Martland, speaking for the majority, quoted the following passage from Kelantin v. Duff Development Company Limited:

But where a question of construction is the very thing referred for arbitration, then the decision of the arbitrator upon that point cannot be set aside by the Court only because the Court would itself have come to a different conclusion. ${ }^{28}$

At 655, Justice Martland quoted a passage from the later House of Lords decision in F.R. Absalom, Limited v. Great Western (London) Garden Village Society, Limited:

[I]t is, I think, essential to keep the case where disputes are referred to an arbitrator in the decision of which a question of law becomes material distinct from the case in which a specific question of law has been referred to him for decision.... The authorities make a clear distinction between these two cases, and, as they appear to me, they decide that in the former case the Court can interfere if and when any error of law appears on the face of the award, but that in the latter case no such interference is possible upon the ground that it so appears that the decision upon the question of law is an erroneous one. ${ }^{29}$

In the Metropolitan Toronto case, the union filed a grievance on the grounds that the Commission had stopped deducting dues for six employees. The decision in the grievance depended upon the interpretation of the collective agreement, which was a

25 See s. 3 of the Arbitration Act (1991).

26 Arbitration $A c t, 1889$ (U.K.), 1889, c. 49.

$27 \quad[1975]$ 1 S.C.R. 630.

28 [1923] A.C. 395 at 409 (H.L.), Viscount Cave L.C.

$29 \quad$ [1933] A.C. 592 at 607 (H.L.), Lord Russell of Killowen. 
matter of law. The Supreme Court held, in effect, that the grievance fell within the category of disputes in which a question of law becomes material rather than the category of disputes in which a specific question of law has been referred for decision. It did so even though the question of law was really the whole dispute.

I think that the Supreme Court's reasoning would apply to the Willick case as follows: Mr. and Mrs. Willick referred a dispute about spousal support. The questions of law (namely causal connection and principles of time-limiting) became material in the decision of the dispute about spousal support, however, those questions of law were not specific questions referred to the arbitrator. If this reasoning is correct, s. 44(3) did not apply, and an appeal on law would lie under either s. 44(1) or s. 44(2) if the appropriate preconditions were met.

The intention of the 1991 Arbitration Act was, in general, to make inapplicable the law that had grown up around the previous Arbitration Act. It is therefore rather embarrassing to have to refer back to the old law. However, I submit that history indicates that the intention was to encapsulate the "very question" proposition, or something like it, in s. $44(3){ }^{30}$

\section{THE CONCLUSION TO BE DRAWN}

Perhaps until it becomes clear that the courts will apply s. 44(3) only to specific questions of law put to arbitrators, drafters who want to be sure that either s. 44(1) or s. 44(2) appeals are available should include in arbitration clauses and agreements a specific statement that $s .44(3)$ is excluded.

\section{VIII. "GROSS ERRORS" OF LAW ON THE FACE OF THE RECORD}

The judge, as noted above, held that the reference of "spousal support" and "such other issues" to arbitration "expressly referred" the questions of law about causal connection and time-limiting. As such, s. 44(3) applied and there was no appeal on law. But the judgment goes on:

Although s. 44(3) provides that an appeal will not be granted if a question of law was expressly referred to the arbitrator, this does not result in a complete ouster of the Court. What if the Arbitrator commits a gross error of law apparent on the face of the record such than an injustice occurs? Surely, the Court would intervene to remedy any such in justice. As Kerans J.A. stated in Penny, supra at 245, in dealing with an appeal from the Workers' Compensation Board, "Who would fail to call for judicial intervention, for example, if the [Workers' Compensation] Appeals Commission started granting divorces?" whether a question of law has been referred to a tribunal for decision, a question which has caused some difficulties in the past": W.H. Hurlburt, "New Legislation for Domestic Arbitrations" (1993) 21 Can. Bus. L.J. 1 at note 71. 
In determining the standard of review to apply under s. 44(3) for an arbitrator's regard for irrelevant considerations, one must visit the "pragmatic or functional" framework in Bibeault, supra. It is clear the legislature's intention in including s. 44(3) was to limit the role of the courts in the arbitration process where the parties have expressly referred a matter to an arbitrator for consideration. Further, the arbitrator in this case is experienced in family law matters and ought to be shown deference. Ronald Foster, Q.C. was chosen because of his knowledge and experience and this must play a large role in the consideration of what standard of review ought to apply. In my opinion, the "patently unreasonableness" standard of review must apply in the facts of this case where the parties allege the arbitrator has grossly erred in law despite a question being expressly referred to the arbitrator for consideration."

As a debating point, the example of an arbitrator purporting to grant a divorce can be answered simply enough. First, no one but the courts mentioned in the Divorce Act can be clothed with power to grant a divorce. Second, the Court could and would declare the arbitration invalid under s. 47(1)(c) of the Arbitration Act on the grounds that "the subject-matter is not capable of arbitration under Alberta law." Alternatively, it could and would set aside the award on the same grounds under s. 45(1)(e) or on the grounds that the award deals with a matter in dispute that is beyond the scope of the arbitration agreement under s. 45(1)(c). The parties cannot grant an arbitrator power to decide anything that affects anyone but themselves, nor can they grant the arbitrator power to do anything illegal.

The important point is that the judgment seems to say that, even if s. 44(3) applies, the court retains a power to quash for error on the face of the record. The judgment does not quote authority for this proposition.

Traditionally, the courts asserted an inherent jurisdiction to set aside arbitration awards for error of law on the face of the award. But the Alberta Court of Appeal held in 1980, in a fully considered decision, ${ }^{32}$ that the Arbitration Act, presumably as it appeared in the 1970 Revised Statutes, had taken away that jurisdiction:

The result of Snider v. Miller, ${ }^{33}$ followed in Alberta for more than 50 years, is that "unless a contrary intention is expressed therein" any submission to arbitration becomes an order of the court and thereby comes under the ambit of the statute. In my view whether or not it becomes an order of the court, a submission is governed by the statute.... In my view the legislature in the Arbitration Act has set forth provisions applicable to all arbitrations. It is therefore not open to a party to an arbitration to contend that he is proceeding under the common law jurisdiction rather than under the Arbitration Act. Each submission comes under the Act so that all subsequent proceedings relate to that statutory jurisdiction. ${ }^{34}$

And later:

" Mijon Holdings v. Edmonton (1980), 12 Alta. L.R. (2d) 88 [hereinafter Mijon].

32 [1923] 3 W.W.R. 1376 (T.D.), aff'd [1924] I W.W.R 1163 (App. Div.).

33 Willick, supra note 1 at 15-16.

$34 \quad$ Mijon, supra note 31 at 93. 
In my view, Snider v. Miller, supra, establishes that the Alberta legislature did attempt "to define comprehensively the scope of the jurisdiction to set aside awards." ${ }^{\text {"3s }}$

The $1991 \mathrm{Act}$, in my submission, shows an even clearer intention to cover the whole field of setting aside awards. First, s. 6 opens with the words:

No court may intervene in matters govemed by this Act, except for the following purposes as provided by this $A c t .^{36}$

Section 37 then says that an award "binds the parties unless it is set aside or varied under sections 44 or 45 ." Sections 44,45 and 47 provide an elaborate scheme of appeals, setting aside of awards, and declarations of invalidity that are surely intended to cover the whole ground. If the judgment is right in saying that there is an inherent residuary power in respect of appeals barred by s. 44(3), it follows that:

(1) the Act confers a right of appeal on law in certain circumstances under ss. 44(1) and (2);

(2) s. 44(3) then says there is no appeal if the parties have expressly referred a question of law to arbitration; and

(3) the common law then steps in to say that, even if there is no appeal, the court has the power to quash for error of law on the face of the record anyway, though the power may exist only if the court is able to characterize the error of law as "gross".

In my submission, the Act excludes such a power even more strongly than the previous one did.

ALRI Report 51 states: "[O]ur proposals would substitute a limited appeal to the Court of Queen's Bench on a question of law for the power to set an award aside for error on the face of the award...." ${ }^{37}$ The subsequent addition of s. 44(2) and, later, of s. 44(3) did not affect that intention.

\section{CONCLUSION}

The 1991 Arbitration Act establishes a legal structure for arbitrations in which court intervention is available to ensure that the parties get due process and have their rights determined according to law. Court intervention is an essential element in that structure. However, the policy of the 1991 Arbitration Act is to restrict court intervention to specific circumstances "as provided in this Act." It imposes a limited appeal on law under s. 44(2) and permits an unrestricted right of appeal on law and fact under $s$. 44(1). 
The decision in Willick deals with some important aspects of the relationship between the courts and the arbitration process. Its application of the "correctness" standard to appeals on questions of law seems correct. Its statement that the "correctness" standard also applies to appeals on questions of fact is not inconsistent with the language of s. 44(1), but in my submission, would be a departure from good judicial policy. Its interpretation of s. 44(3) to include questions of law not specifically referred to the arbitral tribunal for decision would, in my submission, erode and virtually abolish appeals on questions of law under ss. 44(1) and (2) and would be inconsistent with the context of the Act and the context within which the Act was adopted. Its assertion of a judicial power outside the statute to set aside an award for gross error of law on the face of the record is inconsistent both with the letter of the Act and with the policies behind it.

Finally, the judgment demonstrates the importance of deciding what appeals the parties want and of drafting an arbitration clause or reference that reflects their wishes. 